\title{
Effect of salinity on chlorophyll concentration, leaf area, yield and yield components of rice genotypes grown under saline environment
}

\author{
"Y. Ali, Z. Aslam, M. Y. Ashraf and G. R. Tahir \\ Nuclear Institute for Agriculture and Biology, Faisalabad, Pakistan
}

\begin{abstract}
Salt tolerance in eighteen advanced rice genotypes was studied under an artificially salinized (EC $\left.=8.5 \mathrm{dSm}^{-1}\right)$ soil conditions after 90 days of transplanting. The results showed that the yield per plant, chlorophyll concentrations, fertility percentage, and number of productive tillers, panicle length and number of primary braches per panicle of all the genotypes were reduced by salinity. However, genotypes viz. Jhona-349 x Basmati370, NR-1, DM-59418, DM-63275, DM-64198 and DM-38-88 showed better salinity tolerance than others.
\end{abstract}

Key words: Rice, genotypes, salinity, dwarf mutant, chlorophyll

*Corresponding Author, E-mail: yousaf_sem@yahoo.com

\section{Introduction}

Rice is the premier food grain crop of Pakistan for domestic consumption and export occupying an area of 2.2 million hectares (Zia, et al., 1998). Soil salinity is one of the major constraints responsible for low agriculture production in Pakistan. Out of $14.8 \times 10^{6}$ hectares irrigated land; 6 million hectares are salt affected. A loss of Rs. 20 million per year has been estimated on salt affected soils of Pakistan on account of decrease in agriculture production (Anonymous, 2003). Selection of salt tolerant cultivars is one of the most effective methods to increase the productivity of such soils. The major inhibitory effect of salinity on plant growth and yield has been attributed to: 1) osmotic effect 2) ion toxicity 3 ) nutritional imbalance leading to reduction in photosynthetic efficiency and other physiological disorders. Adverse effects of Salinity on seed germination and seedling growth as well as some physiological activities of cultivated plant species have been extensively investigated in Pakistan (Ashraf and Khan, 1993; Ashraf, et al., 1991; Khan, et al., 1995). Generally, the trend and magnitude of adverse changes varied with in species, varieties/genotypes according to the level of Salinization. So far little emphasis has been placed on aspects relevant to photosynthetic efficiency of plants at moderate and high salinities. It has been suggested that by increasing photosynthetic efficiency crop production could be increased. Breeding for salinity tolerant in rice is difficult due to the involvement of several genes controlling the character and lack of sufficient knowledge of the mechanisms controlling salt tolerance (Aktita and Cabusley, 1988 and Yeo, et al., 1990). Therefore the efforts have been made to develop the salt tolerant variety through induced mutations. Mutant lines used in this study are the derivatives of Basmati rice background having good quality grain with strong aroma. The aim of the present investigation is to provide information on the effect of salinity on chlorophyll concentration and yield and yield components of rice genotypes to see if there is any correlation between these variables.

\section{Materials and Methods}

The study was conducted during the years 2001-02 in artificially salinized $(6 \times 6 \times 1 \mathrm{~m})$ concrete tanks located in net-house of Nuclear Institute for Agriculture and Biology (NIAB) Faisalabad (183 m above mean sea level 3124 $\mathrm{N}$ and 73005 E) Pakistan. Salinity was raised by mixing four commercial salts i.e. $\mathrm{Na}_{2} \mathrm{SO}_{4}$ ' $\mathrm{NaCl}, \mathrm{MgCl}_{2}$ and $\mathrm{CaCl}_{2}$ in the ratio of 10:4:1:5 respectively on equivalent basis representing a type of salinity found in most parts of Pakistan (Qureshi, et al., 1977). The experimental material comprised of eighteen varieties/variant/mutant lines (Table 1). The crop was also grown in normal soil 
simultaneously. The soil was fertilized with urea at $185 \mathrm{~kg} / \mathrm{ka}$ and DAP at $130 \mathrm{~kg} / \mathrm{ka}$. Four weeks old seedlings were transplanted with row to plant distance of $20 \mathrm{~cm}$. in randomized complete block design. Ninety days after transplanting, three upper leaves of each tiller of three plants from each genotype were excised from each treatment and replication. Chlorophyll concentration ( $a, b$ and total) of these leaves, were determined according to Arnon (1949). At maturity the number of primary branches per panicle, number of productive tillers, panicle length and fertility percentage were also recorded in 6 genotypes, which showed tolerance against salinity. The harmful effects induced by salinity were computed in percent reduction over control $(\%$ ROC) with the following formula.

\section{$(\%$ ROC $)=$}

$\underline{\text { Value in control - value in saline environment } \times \mathbf{1 0 0}}$ Value in control

Analysis of variance was applied to determine the significance of differences among the treatment and genotypes. Duncans Multiple New Range Test (DMRT) compared differences in mean at 5\% probability (Steel and Torrie, 1980).

\section{Results}

Yield per plant decreased significantly in response to salinity (Table 1) in all rice genotypes. The maximum yield under saline condition was recorded in DM-38-88 and NR1 followed by others. When harmful effect of salinity was noted in the form of percent reduction over control, maximum reduction was observed in Super Basmati, KS-282 and Basmati-385 × NIAB-IRR 9 ranging from 48 $50.6 \%$. DM-25 × NIAB-IRR 9 , NIAB-IRRI9 x DM-25, DM-59418, DM-38-88, DM64198, Jhona-349 $\times$ Basmati-370, NIAB-Rice1 and DM-63275 showed minimum reduction over control for yield per plant, which ranged from $15-36 \%$. The reduction in leaf area (Table 1) of all 18 rice genotypes under salinity stress plants has been attributed to suppressed cell division. Maximum percent reduction over control was noted in NIABIRRI-9, NIAB-Rice-1, DM-25 × NIAB-IRRI9, DM-5-89 and super basmati while DM63275, Jhona-349 $\times$ Basmati-370, DM-59418, DM-38-88, DM-64198 and Basmati-370 $\times$ NIAB-RICE-1 showed minimum percent reduction for leaf area.The biosynthesis of pigment fractions (chlorophyll a, b and total) was affected with salinity stress (Table 2).

Table 1: Effect of salinity on grain yield per plant and flag leaf area of different rice genotypes

\begin{tabular}{|lcccccc|}
\hline & \multicolumn{3}{c}{ Yield per plant (gms) } & \multicolumn{3}{c|}{ Flag leaf area $\left(\mathrm{cm}^{2}{ }^{2}\right)$} \\
\hline Genotypes & Control & $\begin{array}{c}\text { EC=8.5d } \\
\mathrm{Sm}^{-1}\end{array}$ & $\begin{array}{c}\text { Percentage } \\
\text { Reduction over } \\
\text { Control }\end{array}$ & Control & $\begin{array}{c}\text { EC=8.5d } \\
\text { Sm }^{-1}\end{array}$ & $\begin{array}{c}\text { Percentage } \\
\text { reduction } \\
\text { over } \\
\text { control }\end{array}$ \\
\hline DM-63275 & 21.80667 & 13.91667 & $36.18159 \mathrm{CDE}$ & 43.88333 & 40.1 & $8.621338 \mathrm{D}$ \\
\hline NIAB-IRRI-9 & 19.56333 & 13.48333 & $31.07855 \mathrm{DEF}$ & 38.62333 & 20.33333 & $47.3548 \mathrm{~A}$ \\
\hline KS-282 & 16.70667 & 8.323333 & $50.17958 \mathrm{~A}$ & 40.13333 & 31.28333 & $22.0515 \mathrm{C}$ \\
\hline NIAB-RICE-1 & 20.27667 & 14.41667 & $28.90021 \mathrm{EF}$ & 80.89333 & 46.1 & $43.01137 \mathrm{~A}$ \\
\hline DM-25xNIAB-IRRI-9 & 12.89333 & 10.91 & $15.3826 \mathrm{G}$ & 81.73333 & 40 & $51.06036 \mathrm{~A}$ \\
\hline Jhona-349 & 20.55 & 11.44667 & $44.29844 \mathrm{AB}$ & 50.65 & 37.91 & $25.15301 \mathrm{BC}$ \\
\hline DM-5-89 & 16.90667 & 10.52667 & $37.73659 \mathrm{BCD}$ & 61.23333 & 31.37667 & $48.75884 \mathrm{~A}$ \\
\hline NIAB-IRRI-9xDM-25 & 13.28333 & 9.666667 & $27.22708 \mathrm{~F}$ & 72.73667 & 52.56667 & $27.73017 \mathrm{BC}$ \\
\hline Jhona-349xBasmati-370 & 18.46667 & 12.8 & $30.68593 \mathrm{DEF}$ & 48.3 & 39.67 & $17.86749 \mathrm{CD}$ \\
\hline Basmati-370xJhon-349 & 17.56667 & 11.94333 & $32.01142 \mathrm{DEF}$ & 48.43333 & 34.59333 & $28.57536 \mathrm{BC}$ \\
\hline Basmati-370 & 14.16333 & 7.873333 & $44.41044 \mathrm{AB}$ & 43.19333 & 31.32667 & $27.47336 \mathrm{BC}$ \\
\hline DM-59418 & 20.53333 & 14.73 & $28.26298 \mathrm{~F}$ & 47.86333 & 39.51667 & $17.43853 \mathrm{CD}$ \\
\hline Basmati-385xNIAB-IRRI-9 & 16.96 & 8.75 & $48.40802 \mathrm{~A}$ & 48.86333 & 32.78333 & $32.90811 \mathrm{~B}$ \\
\hline Super Basmati & 17.83333 & 8.81 & $50.59812 \mathrm{~A}$ & 62.1 & 32.63333 & $47.45035 \mathrm{~A}$ \\
\hline DM-38-88 & 20.30667 & 14.73333 & $27.44586 \mathrm{~F}$ & 52 & 41.10667 & $20.94871 \mathrm{C}$ \\
\hline DM-64198 & 19.51333 & 14.25 & $26.973 \mathrm{~F}$ & 52.51667 & 42.86667 & $18.37512 \mathrm{CD}$ \\
\hline Basmati-370xNIAB-RICE-1 & 18.09333 & 11.88333 & $34.32204 \mathrm{CDEF}$ & 50.42667 & 40.36667 & $19.94976 \mathrm{C}$ \\
\hline DM-3-89 & 17.36667 & 10.36333 & $40.32633 \mathrm{BC}$ & 59.41333 & 44.68 & $24.79802 \mathrm{BC}$ \\
\hline
\end{tabular}

Mean in the same column sharing the letters did not differ significantly according to DMRT (P-0.05) 
Table 2: Chlorophyll concentrations ( $\mathrm{a}, \mathrm{b}$ and total) of different rice genotypes grown under normal and saline environments

\begin{tabular}{|c|c|c|c|c|c|c|c|c|c|}
\hline \multirow[b]{2}{*}{ Genotypes } & \multicolumn{3}{|c|}{ Chlorophyll (a) } & \multicolumn{3}{|c|}{ Chlorophyll (b) } & \multicolumn{3}{|c|}{ Chlorophyll (Total) } \\
\hline & Control & $\begin{array}{c}\mathrm{EC}=8.5 \mathrm{~d} \\
\mathrm{Sm}^{-1}\end{array}$ & $\begin{array}{c}\text { Percentage } \\
\text { reduction } \\
\text { over } \\
\text { control }\end{array}$ & Control & $\begin{array}{c}\mathrm{EC}=8.5 \mathrm{~d} \\
\mathrm{Sm}^{-1}\end{array}$ & $\begin{array}{l}\text { Percentage } \\
\text { reduction over } \\
\text { control }\end{array}$ & Control & $\begin{array}{c}\mathrm{EC}=8.5 \mathrm{~d} \\
\mathrm{Sm}^{-1}\end{array}$ & $\begin{array}{l}\text { Percentage } \\
\text { reduction over } \\
\text { control }\end{array}$ \\
\hline DM-63275 & 0.540 & 0.389 & $27.97 \mathrm{C}$ & 0.283 & 0.257 & $9.187279 \mathrm{EFG}$ & 0.822567 & 0.645667 & 21.507 CDEF \\
\hline NIAB-IRRI-9 & 0.596 & 0.440 & $26.22 \mathrm{CD}$ & 0.365 & 0.290 & $20.54795 \mathrm{AB}$ & 0.938767 & 0.721267 & $22.84145 \mathrm{BCDE}$ \\
\hline KS-282 & 0.493 & 0.358 & $27.34 \mathrm{C}$ & 0.288 & 0.260 & $9.722222 \mathrm{EFG}$ & 0.7809 & 0.618033 & $20.85663 \mathrm{DEF}$ \\
\hline NIAB-RICE-1 & 0.479 & 0.441 & $7.92 \mathrm{G}$ & 0.280 & 0.256 & $8.571429 \mathrm{FGH}$ & 0.758867 & 0.697933 & $8.012744 \mathrm{I}$ \\
\hline DM-25xNIAB-IRRI-9 & 0.559 & 0.412 & $26.44 \mathrm{CD}$ & 0.299 & 0.280 & $6.354515 \mathrm{GH}$ & 0.8586 & 0.6912 & $19.49985 \mathrm{FG}$ \\
\hline Jhona-349 & 0.523 & 0.392 & $24.99 \mathrm{~B}$ & 0.291 & 0.278 & $4.467354 \mathrm{H}$ & 0.811133 & 0.6704 & $17.35333 \mathrm{GH}$ \\
\hline DM-5-89 & 0.501 & 0.349 & $30.38 \mathrm{~B}$ & 0.301 & 0.252 & 16.27907 BCD & 0.8019 & 0.601333 & $25.01539 \mathrm{AB}$ \\
\hline NIAB-IRRI-9xDM-25 & 0.531 & 0.420 & $20.90 \mathrm{E}$ & 0.279 & 0.251 & $10.03584 \mathrm{EFG}$ & 0.810067 & 0.671333 & $17.12694 \mathrm{GH}$ \\
\hline Jhona-349xBasmati-370 & 0.544 & 0.449 & $17.52 \mathrm{~F}$ & 0.320 & 0.278 & $13.125 \mathrm{DE}$ & 0.864 & 0.7273 & $15.8243 \mathrm{H}$ \\
\hline Basmati-370xJhona-349 & 0.572 & 0.411 & $28.22 \mathrm{C}$ & 0.317 & 0.261 & $17.66562 \mathrm{BC}$ & 0.889533 & 0.6717 & $24.49202 \mathrm{BC}$ \\
\hline Basmati-370 & 0.528 & 0.366 & $30.67 \mathrm{~B}$ & 0.289 & 0.238 & $17.64706 \mathrm{BC}$ & 0.8172 & 0.604867 & $25.9863 \mathrm{AB}$ \\
\hline DM-59418 & 0.556 & 0.405 & $27.20 \mathrm{C}$ & 0.309 & 0.262 & $15.21036 \mathrm{CD}$ & 0.866167 & 0.6672 & $22.97811 \mathrm{BCDE}$ \\
\hline Basmati-385xNIAB-IRRI-9 & 0.491 & 0.370 & $24.70 \mathrm{D}$ & 0.300 & 0.231 & $23 \mathrm{~A}$ & 0.791433 & 0.601267 & $24.03662 \mathrm{BCD}$ \\
\hline Super Basmati & 0.516 & 0.376 & $27.24 \mathrm{C}$ & 0.273 & 0.257 & $5.860806 \mathrm{GH}$ & 0.789333 & 0.632567 & $19.85444 \mathrm{EFG}$ \\
\hline DM-38-88 & 0.560 & 0.392 & $30.01 \mathrm{~B}$ & 0.292 & 0.255 & $12.67123 \mathrm{DEF}$ & 0.8513 & 0.6468 & $24.01885 \mathrm{BCD}$ \\
\hline DM-64198 & 0.602 & 0.404 & $32.89 \mathrm{~A}$ & 0.320 & 0.261 & $18.4375 \mathrm{BC}$ & 0.921933 & 0.665033 & $27.86813 \mathrm{~A}$ \\
\hline Basmati-370xNIAB-RICE-1 & 0.550 & 0.379 & $31.17 \mathrm{AB}$ & 0.301 & 0.277 & $7.973422 \mathrm{GH}$ & 0.5644 & 0.434067 & $15.39454 \mathrm{BCDE}$ \\
\hline DM-3-89 & 0.477 & 0.449 & $5.87 \mathrm{H}$ & 0.277 & 0.258 & $6.859206 \mathrm{GH}$ & 0.498833 & 0.467667 & $4.165616 \mathrm{I}$ \\
\hline
\end{tabular}

Mean in the same column sharing the letters did not differ significantly according to DMRT (P-0.05) 
Table 3: Influence of salinity on (a) number of primary branches per panicle (b) number of productive tillers (c) panicle length (d) fertility percentage of rice genotypes

\begin{tabular}{|c|c|c|c|}
\hline \multirow[b]{2}{*}{ Name of Genotypes } & \multicolumn{2}{|c|}{ Salinity level $\mathrm{d} \mathrm{Sm}^{-1}$} & \multirow{2}{*}{$\begin{array}{l}\text { Percentage increase } \\
\text { over control }\end{array}$} \\
\hline & $\begin{array}{c}\text { Control } \\
(\mathrm{EC}=1.80)\end{array}$ & $\mathrm{EC}=8.5$ & \\
\hline \multirow[t]{4}{*}{ DM-59418 } & a-10.5 & 8.6 & 18.09 \\
\hline & b-10.38 & 08.03 & 22.64 \\
\hline & $\mathrm{c}-35.52$ & 28.97 & 18.44 \\
\hline & d-91.88 & 70.42 & 23.36 \\
\hline \multirow[t]{4}{*}{ DM-64198 } & a-11.1 & 8.7 & 21.62 \\
\hline & b-11.86 & 08.35 & 29.68 \\
\hline & $c-24.76$ & 22.67 & 08.44 \\
\hline & d-97.00 & 84.59 & 12.79 \\
\hline \multirow[t]{4}{*}{ Jhona-349 x Basmati-370 } & a-12.0 & 9.4 & 21.66 \\
\hline & b-11.24 & 08.40 & 25.27 \\
\hline & c-28.56 & 22.77 & 20.27 \\
\hline & d-94.04 & 85.53 & 09.05 \\
\hline \multirow[t]{4}{*}{ DM-63275 } & a-10.95 & 8.8 & 19.63 \\
\hline & b-13.90 & 08.00 & 42.45 \\
\hline & $\mathrm{c}-31.34$ & 27.80 & 11.01 \\
\hline & d-91.90 & 69.35 & 24.54 \\
\hline \multirow[t]{4}{*}{ NIAB-RICE-1 } & a-12.2 & 9.8 & 19.67 \\
\hline & b-08.87 & 06.27 & 29.31 \\
\hline & c-29.73 & 25.67 & 13.66 \\
\hline & $d-87.73$ & 74.19 & 15.43 \\
\hline \multirow[t]{4}{*}{ DM-38-88 } & a-12.3 & 10.2 & 17.07 \\
\hline & b-08.48 & 05.92 & 30.19 \\
\hline & c-29.95 & 25.40 & 15.19 \\
\hline & d-84.30 & 71.01 & 15.77 \\
\hline
\end{tabular}

$\mathrm{DM}=$ Dwarf mutant

DM-64198, Basmati-370 and DM-5-89 showed maximum percent reduction over control for chlorophyll total concentration and were graded as sensitive to salinity stress.Genotypes DM-3-89, NIAB-Rice-1, Jhona-349 $\times$ Basmati-370 and NIAB-IRR $9 \times$ DM-25 minimum reduction in chlorophyll concentrations and were graded as salt tolerant. Influence of salinity on yield components i.e. number of primary braches per panicle, number of productive tillers per plant, panicle length and fertility percentage is given in (Table 3). Results indicated that percent increase over control for number of primary braches per panicle ranged from 17.07-21.66, for number of productive tillers per plants 22.64-42.45, panicle length $(\mathrm{cm}$.) 8.44-20.27 and fertility percentage ranged from 9.0524.54 in six genotypes tested. All the six genotypes were graded as salt tolerant with respect to yield components.

\section{Discussion and Conclusion}

When plants are grown under saline conditions, as soon as the new cell starts its elongation process, the excess of salts modifies the metabolic activities of the cell wall causing the deposition of various materials which limit the cell wall elasticity. Secondary cell wall sooner, cell walls become rigid and consequently the turgor pressure efficiency in cell enlargement is decreased. The other expected causes of the reduction in yield per plant, leaf area and yield components in rice could be the shrinkage of the cell contents, reduced development and differentiation of tissues, unbalanced nutrition, damage of membrane and disturbed avoidance mechanism. The reduction in leaf area, yield and yield components under saline conditions were also due to reduced growth as a result of decreased water uptake, toxicity of sodium and chloride in the shoot cell as well as reduced photosynthesis. Reduction in chlorophyll concentrations is probably due to the inhibitory effect of the accumulated ions of various salts on the biosynthesis of the different chlorophyll fractions. Salinity affects the strength of the forces bringing the complex pigment protein- 
liquid, in the chloroplast structure. As the chloroplast in membrane bound its stability is dependent on the membrane stability which under high salinity condition seldom remains intact due to which reduction in chlorophyll was recorded Salt tolerance is not a function of single organ or plant attribute, but it is the product of all the plant attributes. Therefore a genotype exhibiting relative salt tolerance for all the plant attributes may be ideal one. Fortunately the mutants studied viz. DM59418, DM-64198, and Jhona-349 × Basmati370, DM-63275, NIAB-Rice-1 and DM-38-88 has shown comparatively minimum salinity induced reduction for the plant attributes. In this study some genotypes showed tolerance to salinity for the plant attributes that 6 genotypes lacked. The genotypes could be used as donors for these further improvements of mutant lines to establish definite relation with yield, chlorophyll concentration and leaf area. Further study would be initiated with this basic information. By using these mutant lines in breeding Programmed an improved ideotype of rice having higher chlorophyll concentration, more leaf area, early and better yield potential will be selected. This genotype possessing salt tolerance character will help in boosting up rice production in salt-affected soils. Therefore a genotype exhibiting relative salt tolerance for all the plant attributes may be ideal one. Fortunately the mutants studied viz. DM59418, DM-64198, and Jhona-349 $\times$ Basmati370, DM-63275, NIAB-Rice-1 and DM-38-88 has shown comparatively minimum salinity induced reduction for the plant attributes. In this study some genotypes showed tolerance to salinity for the plant attributes that 6 genotypes lacked. The genotypes could be used as donors for these further improvements of mutant lines to establish definite relation with yield, chlorophyll concentration and leaf area. Further study would be initiated with this basic information. By using these mutant lines in breeding Programmed an improved ideotype of rice having higher chlorophyll concentration, more leaf area, early and better yield potential will be selected. This genotype possessing salt tolerance character will help in boosting up rice production in salt-affected soils.

\section{Acknowledgements}

The authors are thankful to Dr. S. Sarwar Alam for kind reviewing of the manuscript and providing valuable comments.

\section{References}

Akita, S. and G. S. Cabuslay, Physiological basis of differential response to salinity in rice cultivars. In: Proc. $3^{\text {rd. }}$ Int. Symp. Genet. Aspects plant Minner. Nutr. Braunschwing, German. 27, 1988

Anonymous, Agricultural statistics of Pakistan. Government of Pakistan, Ministry of Food, Agricultural and Live Stock, Economic Wing, Islamabad, 2003

Arnon, D. T., Copper enzymes in isolated chloroplasts. Poly phenoloridase in Beta vulgaris, Plant physiol. 24: 1-18, 1949

Ashraf, M. Y., M. A. Khan, and S. S. M. Naqvi, Effect of salinity on seedling growth and solute accumulation in two wheat genotypes. Rachis, 10: $303,1 \quad 1991$

Ashraf, M. Y., A. H., Khan. Effect of sodium chloride on growth and nitrogen status of sorghum. Inter Symp. On current developments in salinity and drought tolerance of plants. S. S. M. Naqvi, $R$.

Khan, A. H. M. Y., Ashraf, S. S. M. Naqvi, B. Khanzada, and M. Ali, Growth ion and solute contents of sorghum grown under $\mathrm{NaCl}$ and $\mathrm{Na}_{2} \mathrm{SO}_{4}$ salinity stress Acta Physiol. Plant, 17: 261-268, 1995

Qurehsi R. H., M. Salim, Z. Aslam and G. R. Sandhu, An improved gravel culture technique for salt tolerant studies on plants. Pak. J. Agri. Sci: 1411 18, 1977

Steel, R. G. D., J. H. Torrie, M. S. Principles, M. Aslam, R. M. B. Khan, M. B. Baig and A. Ali, Assessment of nitrogen availability in calcareous soils under rice based cropping system. Pak. J. Soil Sci., 15: 166-173, 1980

Yeo, A. R., M. E. Yeo, S. A. Flowers and T. J. Flowers, Screening of rice (Oryza Sativa L.) genotypes for physiological characters contributing to salinity resistance and their relationship to overall performance. Theo. Appl. Genet. 79: 377-384, 1990

Zia, M. S., M. Aslam, R. M. B. Khan, M. B. Baig, and A. Ali. Assessment of nitrogen availability in calcareous soils under based cropping system. Pak. J. Soil Sci., 15: 166-173, 1998 
